\title{
STRATIGRAPHIC DIVISION OF HOLOCENE LOESS IN CHINA
}

\author{
WEIJIAN ZHOU, ZHISHENG AN
}

Xian Laboratory of Loess and Quaternary Geology, Chinese Academy of Sciences P.O. Box 17, Xian 710061, Shaanxi Province, China

and

\section{J. HEAD}

Quaternary Dating Research Centre, Research School of Pacific and Asian Studies Australian National University, Canberra, ACT 0200 Australia

\begin{abstract}
Loess deposition within the Loess Plateau of China records the history of environmental change over the last $2.5 \mathrm{Myr}$. Loess-paleosol sequences of the last $10 \mathrm{ka}$, which have preserved information of global climate change, relate closely to human occupation of the area. Hence, studies of the deposition and development of Holocene loess are significant for studying environmental change and problems associated with engineering geology. We present here stratigraphic relations among four profiles from the south, west and center of the Loess Plateau. On the basis of ${ }^{14} \mathrm{C}$ radiometric and AMS dates of organic material extracted from the paleosols, together with magnetic susceptibility measurements down each profile, we discuss Holocene stratigraphic divisions within the Loess Plateau, and suggest that the Holocene optimum, characterized by paleosol complexes, occurred between 10 and $5 \mathrm{ka}$ BP. From $5 \mathrm{ka}$ BP to the present, neoglacial activity is characterized by recently deposited loess.
\end{abstract}

\section{INTRODUCTION}

Within the Loess Plateau, located between the Huang He (Yellow River) and the Wei River (Fig. 1), Holocene loess-paleosol sequences frequently developed, together with paleosols alternately interbedding with aeolian dust, loess, lacustrine and fluvial sediments. Textural properties of the various sequences indicate that the accumulation of loess has been continuous, but that the rate of accumulation has varied considerably. When the winter monsoon was dominant, the accumulation rate of loess was rapid, and when the summer monsoon was dominant, the loess accumulation rate was slow, resulting in soil formation. Therefore, the development of loess and paleosol sequences has produced a record of the history of fluctuations of the east Asian monsoon (An et al. 1990).

The study of loess deposits in China has been encouraged because of problems associated with the ecology of the Loess Plateau and the utilization of its resources. Qiao et al. (1985) carried out a series of ${ }^{14} \mathrm{C}$ determinations on calcium carbonate and total organic matter from loess-paleosol sequences formed during the last $30 \mathrm{ka}$. Based on these dates, Zheng (1984) divided the Holocene loess sequences of the middle reaches of the Huang $\mathrm{He}$ into three formations: 1) the late Holocene Xifeng Formation (2-3 ka BP); 2) the middle Holocene Longxi Formation (4.6-7.4 BP); and 3) the early Holocene Luochuan Formation. Because inorganic carbonate deposits in loess may consist of secondary and debris carbonates containing young and old carbon, it is difficult to obtain a true ${ }^{14} \mathrm{C}$ age. Difficulties also occur in dating organic material from paleosols, because the presence of younger plant rootlets and translocated organic substances can affect their reliability.

We have obtained a reliable ${ }^{14} \mathrm{C}$ chronology from a loess-paleosol section at Bei Zhuang Cun (Weinan County) by separating different chemical fractions from the organic component of the paleosols, and by comparing their ${ }^{14} \mathrm{C}$ ages (Head, Zhou and Zhou 1989; Zhou, Zhou and Head 1990). In most cases, the sodium-hydroxide-soluble (humic acid) fraction after solvent extraction of low-molecular-weight organic matter yielded the most reliable ages. The ${ }^{14} \mathrm{C}$ ages can be compared 
with known-age pottery in paleosols toward the top of the profile, and with ${ }^{14} \mathrm{C}$ ages obtained from cellulose fractions of co-existing wood fragments toward the bottom of the profile.

We have used the same techniques to separate chemical fractions for dating from the organic component of paleosol samples collected from three other sites, Renjiahutong, Bai Ma Po and Baxie. Based on these ${ }^{14} \mathrm{C}$ ages and magnetic susceptibility measurements, the authors propose a "twofold" division of Holocene loess, rather than a "threefold" division.

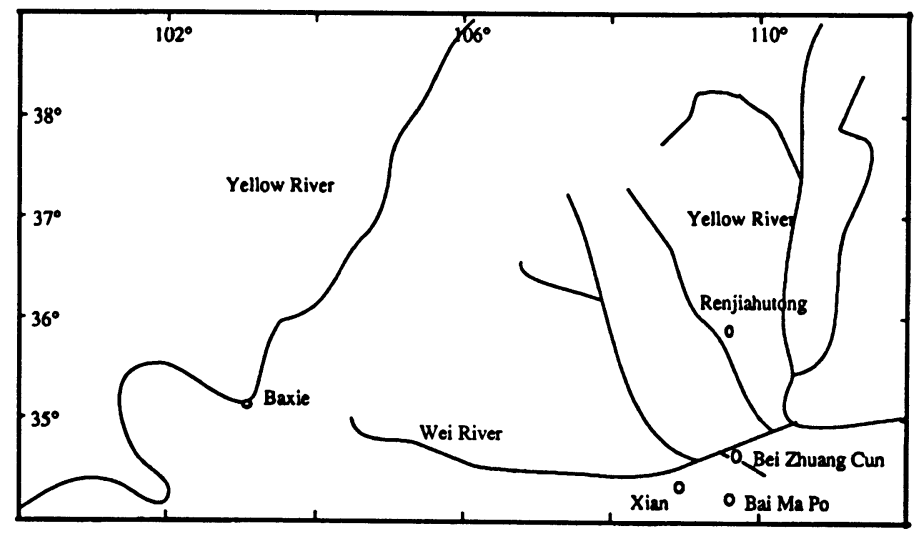

Fig. 1. Location of sites studied

\section{METHODS}

\section{Radiocarbon Determinations}

The paleosol samples were wet-sieved using a $0.5-\mathrm{mm}$ sieve, treated with hot $1 \mathrm{M} \mathrm{HCl}$, rinsed with distilled water, then dried and crushed to $<0.5 \mathrm{~mm}$. Successive solvent extractions were carried out in an ultrasonic bath (McIver 1962), using redistilled solvents. Chloroform/ethanol (2:1) was followed by ethanol, then multiple extractions with water, until no solvent could be detected within the samples. After each extraction, the solvent was separated as rapidly as possible by vacuum filtration, and the residue was air-dried. As described previously (Head, Zhou and Zhou 1989; Head 1979), we used this sequence of solvents both to provide a progressive increase in polarity and to facilitate removal of the organic solvents from the samples.

$\mathrm{NaOH}$-soluble and -insoluble fractions were prepared from the samples after solvent extraction by adding hot $0.5 \mathrm{M} \mathrm{NaOH}$ solution, stirring periodically for at least $1 \mathrm{~h}$, then filtering off the $\mathrm{NaOH}$ liquor, which was then acidified. The dark brown precipitates that were formed were rinsed by centrifugation, and then dried at low temperature. The sodium-hydroxide-insoluble residues were acidified, rinsed and dried. At times, the $\mathrm{NaOH}$-soluble fraction was either unobtainable or it was not large enough for dating. Table 1 shows the results. In most cases, the solvent extraction step is sufficient to remove younger organic material moving down the profiles; in some cases it is not, hence the difference between the $\mathrm{NaOH}$-soluble and -insoluble fractions, also between successive $\mathrm{NaOH}$ soluble fractions. 
TABLE 1. Results of ${ }^{14} \mathrm{C}$ Determinations of Chemical Fractions of the Organic Component of Holocene Paleosol Samples from Four Sections Within the Loess Plateau, China

\begin{tabular}{|c|c|c|c|c|}
\hline Depth (m) & Lab no. & Chemical fraction & ${ }^{14} \mathrm{C}$ age (BP) & $\begin{array}{c}\text { Magnetic } \\
\text { susceptibility } \\
\text { age (BP) }\end{array}$ \\
\hline \multicolumn{5}{|c|}{ Renjiahutong Brickyard, Luochuan } \\
\hline \multirow[t]{2}{*}{1.1} & ANU-5942 & $\mathrm{NaOH}$ soluble & $4830 \pm 220$ & 5000 \\
\hline & & $\mathrm{NaOH}$ insoluble & $4700 \pm 220$ & \\
\hline 2.1 & ANU-5943 & $\mathrm{NaOH}$ insoluble & $10,420 \pm 310$ & 10,000 \\
\hline \multirow[t]{2}{*}{2.6} & ANU-5944 & $\{\mathrm{NaOH}$ soluble & $12,980 \pm 720$ & 14,000 \\
\hline & & $\mathrm{NaOH}$ insoluble & $4180 \pm 700$ & \\
\hline \multicolumn{5}{|c|}{ Bei Zhuang Cun Profile, Weinan } \\
\hline \multirow[t]{2}{*}{3.0} & ANU-6201 & $\{\mathrm{NaOH}$ soluble & $2540 \pm 250$ & 3000 \\
\hline & & | $\mathrm{NaOH}$ insoluble & $3270 \pm 200$ & \\
\hline 3.6 & XLLQ-111 & $\mathrm{NaOH}$ insoluble & $5720 \pm 100$ & 4300 \\
\hline 6.0 & XLLQ-104 & $\mathrm{NaOH}$ insoluble & $9600 \pm 170$ & 9600 \\
\hline 9.5 & ANU-6393 & $\mathrm{NaOH}$ soluble & $14,000 \pm 170$ & 14,200 \\
\hline \multirow[t]{3}{*}{13.5} & XLLQ-26 & Holocellulose & $26,080 \pm 270$ & \\
\hline & XLLQ-45 & $\mathrm{NaOH}$ soluble & $27,440 \pm 320$ & \\
\hline & XLLQ-48 & $\mathrm{NaOH}$ insoluble & $21,000 \pm 500$ & \\
\hline \multicolumn{5}{|c|}{ Bai Ma Po Profile, Lantian } \\
\hline \multirow[t]{4}{*}{1.0} & ANU-5948/1 & NaOH soluble (1) & $5370 \pm 120$ & 4500 \\
\hline & ANU-4948/2 & $\{\mathrm{NaOH}$ soluble (2) & $6700 \pm 140$ & \\
\hline & ANU-4948/3 & $\mathrm{NaOH}$ soluble (3) & $6970 \pm 280$ & \\
\hline & ANU-4948/4 & $\mathrm{NaOH}$ insoluble & $6040 \pm 610$ & \\
\hline \multicolumn{5}{|c|}{ Baxie Profile, Dongxiang } \\
\hline 5.25 & XLLQ-442 & $\mathrm{NaOH}$ insoluble & $5800 \pm 220$ & 5400 \\
\hline 7.75 & XLLQ-416 & $\mathrm{NaOH}$ insoluble & $9330 \pm 220$ & 9500 \\
\hline \multirow[t]{3}{*}{9.25} & XLLQ-415 & $\mathrm{NaOH}$ insoluble & $9830 \pm 270$ & 10,000 \\
\hline & AA-6441 & $\mathrm{NaOH}$ soluble (2) & $9580 \pm 85$ & \\
\hline & AA-6442 & $\mathrm{NaOH}$ soluble (3) & $9695 \pm 95$ & \\
\hline 9.75 & XLLQ-441 & $\mathrm{NaOH}$ insoluble & $11,110 \pm 220$ & 10,800 \\
\hline
\end{tabular}

\section{Magnetic Susceptibility Measurements}

Figure 2 shows magnetic susceptibility curves for each of the four profiles examined in this study. An et al. (1990) discussed previously the chronology of these profiles, and Kukla and An (1989) and Zhou and An (1991) calculated time scales from the conversion equation of susceptibility against time. These curves are based on the marker ages of $10 \mathrm{ka}$ BP as the start of the Holocene, and $0 \mathrm{BP}$ as the surface. Using the conversion equation and the marker ages, we list approximate magnetic susceptibility ages alongside the ${ }^{14} \mathrm{C}$ ages in Table 1 . Heller and Liu (1984) observed that loess has low magnetic susceptibility, because of low Fe content, Fe being in the form of hematite. Paleosols produce a strong magnetic susceptibility signal, indicating a high magnetite content. 


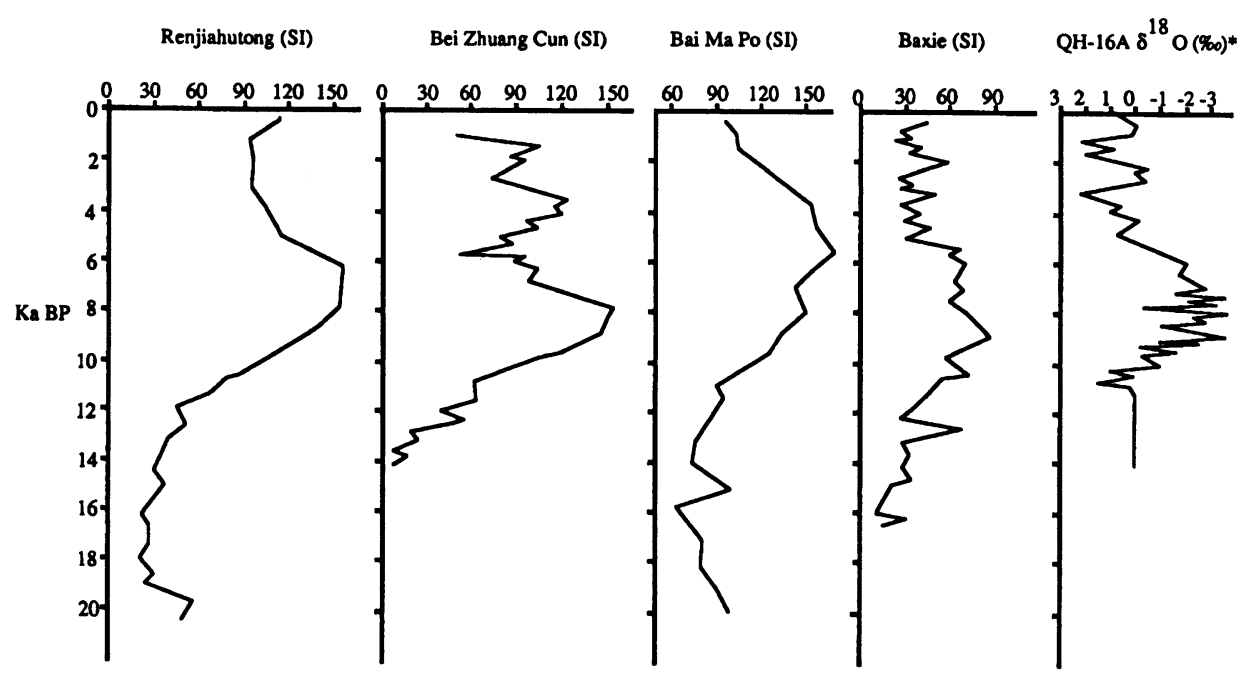

Fig. 2. Susceptibility time-scale curves of loess profiles in Renjiahutong, Bei Zhuang Cun, Bai Ma Po and Baxie. ${ }^{*} \delta^{18} \mathrm{O}(\%)$ curve of ostracod shells from the QH-16A core in Qinghai Lake (Zhang Penxi et al. 1989)

One may interpret the physical significance of magnetic susceptibility in two ways. One is that the accumulated rate of magnetic minerals is constant within a time range of $1 \mathrm{ka}$. Changes in the magnetic susceptibility values in loess-paleosol sequences reflect changes in the dust accumulation rates from the geological source area. High susceptibility corresponds to low dust accumulation rate, indicating soil development. Low susceptibility values correspond to high rates of dust accumulation; hence, loess layers form.

The second interpretation is that fine magnetite in soils results from pedogenic processes; thus, susceptibility fluctuations indicate the degree of pedogenesis. When summer monsoons have a significant effect on local climate, with high temperatures and precipitation, vegetation density increases, and developing soils have a high content of fine magnetite grains. Thus, magnetic susceptibility fluctuations can be related to the amount of precipitation produced by the east Asian monsoons, and provide a proxy index of climatic change.

\section{HOLOCENE STRATIGRAPHY OF THE LOESS PLATEAU}

We studied four profiles of loess-paleosol sequences in the Loess Plateau of China (Fig. 2): Renjiahutong, Bei Zhuang Cun, Bai Ma Po and Baxie.

The Renjiahutong Brickyard profile, Luochuan County, Shaanxi Province $\left(35^{\circ} 45^{\prime} \mathrm{N}, 109^{\circ} 25^{\prime} \mathrm{E}\right)$ (Fig. 1) consists of a $0.6-\mathrm{m}$-thick top layer of cultivated soil and loess overlying a weakly pedogenic 0.55 -m-thick paleosol complex. We took a sample from the bottom of this complex and obtained conventional ${ }^{14} \mathrm{C}$ ages (Stuiver and Polach 1977) of $4830 \pm 220 \mathrm{BP}$ (ANU-5942A), and $4700 \pm 220$ $\mathrm{BP}$ (ANU-5942B) from the $\mathrm{NaOH}$-soluble and -insoluble fractions, respectively, of the organic component (Table 1). Because these results are not significantly different from each other, we determined an error-weighted mean age of $4765 \pm 180$ BP (Gupta and Polach 1985). We also collected a sample from the bottom of the 1.05-m-thick complex below this level, and obtained a conventional ${ }^{14} \mathrm{C}$ age of $10,420 \pm 310 \mathrm{BP}$ (ANU-5943) from the $\mathrm{NaOH}$-insoluble fraction of the organic component. No NaOH-soluble fraction was obtained from this sample. A 0.3-m-thick layer of 
Holocene loess underlies this complex, which, in turn, is underlain by a layer of scattered carbonate nodules with a mean diameter of $5-10 \mathrm{~mm}$, at $2.6 \mathrm{~m}$ below the top of the profile. The $\mathrm{NaOH}$-soluble fraction of the organic component of the nodules has an age of 12,980 $\pm 720 \mathrm{BP}$ (ANU-5944). The $\mathrm{NaOH}$ - insoluble fraction of the nodules has an age of $4180 \pm 310 \mathrm{BP}$ (ANU-5944), indicating the presence of younger contaminants. Underlying this layer is Malan Loess (L1) (Liu 1985).

As Figure 3 shows, from ca. $13 \mathrm{ka}$ BP downward, magnetic susceptibility in the Luochuan profile is as low as 40 (SI), indicating a cold and dry climate, ideal for loess deposition. In Figure 3, this period corresponds to the loess sequence at $2.2 \mathrm{~m}$ depth (Malan Loess). The slight rise in magnetic susceptibility shown in Figure 2 probably corresponds to the nodule layer, from which a ${ }^{14} \mathrm{C}$ age of $12,980 \pm 720$ BP was obtained. From $c a$. $11 \mathrm{ka}$ BP upward, susceptibility values increase rapidly. This corresponds to the ${ }^{14} \mathrm{C}$ age of $10,420 \pm 310 \mathrm{BP}$, shown in Figure 3. Magnetic susceptibility reaches a maximum $c a .10-6 \mathrm{ka} \mathrm{BP}$, reflecting a warmer and wetter environment. From $6 \mathrm{ka} \mathrm{BP}$ upward, magnetic susceptibility decreased, indicating a change to a drier and colder climate. In Figure 3 , the onset of cooler, drier weather is indicated by the formation of a weakly pedogenic paleosol with a mean ${ }^{14} \mathrm{C}$ age of $4765 \pm 180 \mathrm{BP}$ at the base of this layer. From Table 1 , the magnetic susceptibility chronology follows the ${ }^{14} \mathrm{C}$ chronology reasonably well, although a tight correlation is not possible due to the limits of accuracy in both techniques.

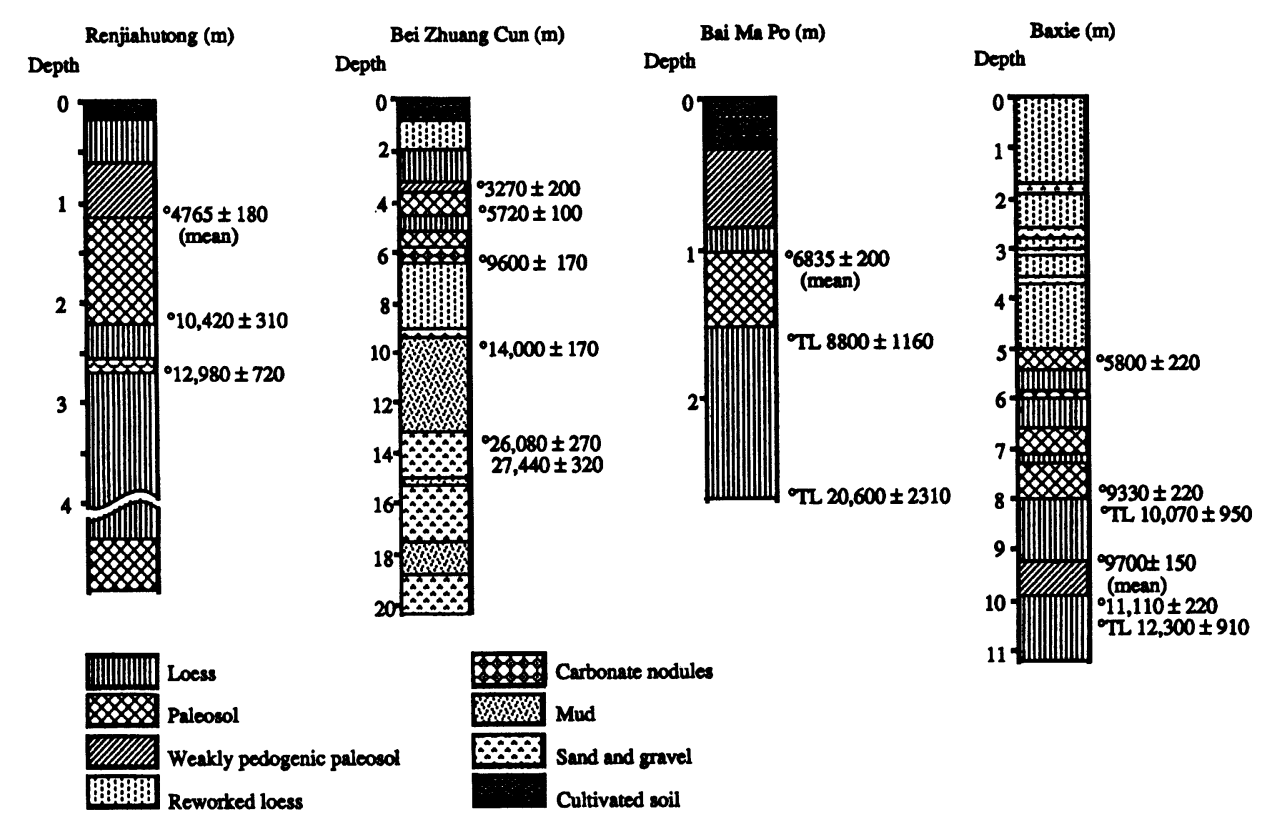

Fig. 3. Holocene stratigraphic correlation of Renjiahutong, Bei Zhuang Cun, Bai Ma Po and Baxie

The Bei Zhuang Cun profile is located on the east bank of the Zhuoshui River (Muddy River), a western tributary of the You River, in Weinan County, Shaanxi Province $\left(34^{\circ} 30^{\prime} \mathrm{N}, 109^{\circ} 30^{\prime} \mathrm{E}\right.$ ) (Fig. 1). Below the top layer (Fig. 3) of cultivated soil and loess $(\sim 2 \mathrm{~m})$, produced both by flooding and agriculture, is a 4-m-thick loess-paleosol sequence consisting of 2 loess layers and 3 paleosol layers. The upper paleosol contains fragments of red pottery, and the $\mathrm{NaOH}$-insoluble fraction of the organic component has been dated to $3270 \pm 200 \mathrm{BP}$ (ANU-6201). This age agrees with historical evidence for the advent of this style of pottery. The $\mathrm{NaOH}$-soluble fraction of this sample gave an 
age of $2540 \pm 250 \mathrm{BP}$, and is considered to be contaminated by younger material. The middle paleosol dates to $5720 \pm 100 \mathrm{BP}$ (XLLQ-111, NaOH-insoluble fraction). No NaOH-soluble fraction was obtained. At the base of the lowest paleosol is a scattered layer of carbonate nodules. The organic component of the nodules has a ${ }^{14} \mathrm{C}$ age of $9600 \pm 170 \mathrm{BP}$ (XLLQ-104, NaOH-insoluble fraction). $\mathrm{No} \mathrm{NaOH}$-soluble fraction was obtained. Below this loess-paleosol sequence ( $c a .8 .6 \mathrm{~m}$ below the surface) is a 3-m-thick layer of reworked loess indicating a dynamic fluvial environment. At 9-13.5 $\mathrm{m}$ is a layer of mud, containing a large quantity of fossil plant residue (tree trunks and reed roots), indicating a swampy or shallow lacustrine environment. At $9.5 \mathrm{~m}$, we obtained a ${ }^{14} \mathrm{C}$ age of 14,000 $\pm 170 \mathrm{BP}$ (ANU-6393) for the $\mathrm{NaOH}$-soluble fraction. We dated both organic fractions and woodcellulose fractions of samples collected near the bottom of this layer, which yielded ${ }^{14} \mathrm{C}$ ages for wood cellulose and organic $\mathrm{NaOH}$-soluble fractions of 26,080 \pm 270 (XLLQ-26) and 27,440 \pm 320 $\mathrm{BP}(\mathrm{XLLQ}-48)$. The $\mathrm{NaOH}$-insoluble fraction of the organic component gave a ${ }^{14} \mathrm{C}$ age of $21,000 \pm$ $500 \mathrm{BP}$ (XLLQ-48), indicating contamination. The bottom layer of the profile consists of $2.95 \mathrm{~m}$ of sand and gravel (Head, Zhou and Zhou 1989; Zhou, Zhou and Head 1990). Two other fractions, ANU-5948/1, (NaOH-soluble fraction) and ANU-5948 (NaOH-insoluble fraction) were dated, but because they yielded significantly younger ages caused by insufficient removal of younger contamination, they were not used for the calculation of the mean age for this sample.

The susceptibility curve of the Bei Zhuang Cun profile (Fig. 2) shows a small peak (susceptibility index (SI) reaches 60 at $c a .12 \mathrm{ka} \mathrm{BP}$ ), then a larger peak between 10 and $7 \mathrm{ka} \mathrm{BP}$ (SI reaches $c a$. 150). From $4 \mathrm{ka} \mathrm{BP}$, upward, the SI decreases, with short increases from $c a .3 .5 \mathrm{ka}$ BP and $c a .1 .5-2$ ka BP. The ${ }^{14} \mathrm{C}$ chronology in Figure 3 shows a gap between $\mathrm{ca} .10$ and $14 \mathrm{ka} \mathrm{BP}$, but even with this drawback, the magnetic susceptibility chronology seems to fit reasonably well with the changes in sediment type, as can be seen from Table 1 .

The Bai Ma Po profile, Lantian County, Shaanxi Province $\left(34^{\circ} 10^{\prime} \mathrm{N}, 109^{\circ} 19^{\prime} \mathrm{E}\right)$ (Fig. 2), consists of cultivated soil overlying a loess and paleosol complex $\left(\mathrm{S}_{0}\right)$ (Liu 1985). Underlying cultivated soil is a weakly pedogenic soil, the lower part of which is strongly pedogenic paleosol. Underlying the complex is Malan loess $\left(\mathrm{L}_{1}\right)$. The total thickness of the profile is $7.5 \mathrm{~m}$, but Holocene stratigraphy occupies only $1.5 \mathrm{~m}$. The top of the paleosol from the lower complex has a ${ }^{14} \mathrm{C}$ age of $6970 \pm 280$ BP (ANU-5948/2, NaOH-soluble fraction), and $6700 \pm 140 \mathrm{BP}$ (ANU-5948/3, NaOH-soluble fraction). These two ${ }^{14} \mathrm{C}$ ages are not significantly different from each other, and a mean age of $6835 \pm$ $200 \mathrm{BP}$ can be used for the paleosol. The near bottom of the paleosol complex has a thermoluminescence (TL) age of $8800 \pm 1160 \mathrm{BP}$ (An et al. 1991).The susceptibility curve of the Bai Ma Po profile (Fig. 2) is standardized using the bottom of the paleosol as $10 \mathrm{ka} \mathrm{BP}$, and correlates reasonably well as magnetic susceptibility starts increasing to a peak $c a .6 \mathrm{ka} \mathrm{BP}$, decreasing consistently to the present. A significant discrepancy exists between the ${ }^{14} \mathrm{C}$ chronology $(6835 \pm 200 \mathrm{BP})$ and a magnetic susceptibility age of $c a .5 \mathrm{ka} \mathrm{BP}$ at the top of the paleosol complex (Table 1), but many more ${ }^{14} \mathrm{C}$ ages are needed to define this period more accurately.

The Baxie profile, Donxiang County, Gansu province $\left(36.7^{\circ} \mathrm{N}, 103.4^{\circ} \mathrm{E}\right)(\mathrm{Fig} .3)$ is located in a river valley at the southwest margin of the Loess Plateau, $65 \mathrm{~km}$ southwest of Lanzhou (An et al. 1993; Zhou et al. 1992). The top layer is $5 \mathrm{~m}$ thick, consisting of loess reworked under fluvial conditions interspersed with a series of thin sand layers. This overlies $3 \mathrm{~m}$ of loess-paleosol complex, consisting of 4 paleosol and 3 loess layers. The $\mathrm{NaOH}$-insoluble fraction of the upper paleosol near the top dates to $5800 \pm 220 \mathrm{BP}$ (XLLQ-442), and the $\mathrm{NaOH}$-insoluble fraction of a sample taken near the base of the lowest paleosol dates to $9330 \pm 220 \mathrm{BP}$ (XLLQ-416). The underlying layer consists of 1.2-m-thick upper Malan Loess, and the top of the loess yields a TL age of 10,070 $\pm 950 \mathrm{BP}$ (Zhou et al. 1992). Below this is $1.3 \mathrm{~m}$ of weakly pedogenic paleosol, the top of which $(9.25 \mathrm{~m}$ ) has 
a series of ${ }^{14} \mathrm{C}$ ages, $9830 \pm 270 \mathrm{BP}(\mathrm{NaOH}$-insoluble, XLLQ-415), $9580 \pm 85(\mathrm{NaOH}$ soluble, AA$6441)$, and $9695 \pm 95 \mathrm{BP}(\mathrm{NaOH}$ soluble, AA-6442). We calculated an error-weighted mean (Gupta and Polach 1985) as a representative age of $9700 \pm 150 \mathrm{BP}$ for this sample. Another ${ }^{14} \mathrm{C}$ age on the $\mathrm{NaOH}$-insoluble fraction of a sample taken from close to the middle of this paleosol $(9.75 \mathrm{~m})$ was $11,110 \pm 220 \mathrm{BP}$ (XLLQ-441). A TL age of 12,300 $\pm 910 \mathrm{BP}$ (Zhou et al. 1992) was obtained from the Malan loess underlying this paleosol complex.

The Baxie profile has an obvious peak of magnetic susceptibility during the period 12-13 ka BP (Fig. 2). This peak could coincide with the change from loess to paleosol in Figure 3. From $11 \mathrm{ka}$ BP upward, magnetic susceptibility increases rapidly, with a maximum peak at $c a .9 .5 \mathrm{ka} \mathrm{BP}$, decreasing slowly to $c a .5 \mathrm{ka} \mathrm{BP}$, and then decreasing rapidly. This chronology differs little from the chronology obtained by ${ }^{14} \mathrm{C}$ and TL determinations (Table 1), and hence can be considered representative of this profile.

The profiles discussed above show low susceptibility values at $12 \mathrm{ka} B P$, representing cold and dry states. There was an obvious fluctuation ca. $12 \mathrm{ka} \mathrm{BP}$, susceptibility increased and a weakly pedogenic paleosol developed in the profiles with high resolution. Between 10 and $5 \mathrm{ka} \mathrm{BP}$, susceptibility reached high values, and paleosol complexes developed in the Loess Plateau. From $5 \mathrm{ka} \mathrm{BP}$, loess was redeposited, although several warm and humid fluctuations occurred. The susceptibility curve also reflects a high-resolution profile in the west of the Loess Plateau where as many as four Holocene paleosols have developed. In the southern area of the Loess Plateau, because of slower dust accumulation, and a warmer and more humid climate suitable for soil development, 1-2 paleosol complexes are evident.

\section{Discussion}

The threefold stratigraphic division of Chinese Holocene loess is mainly based on the north European model, and has the same boundaries as the Blytt-Sernander scheme. The susceptibility curves for the four profiles in Figure 2 reflect the common tendency for higher SI values between 10 and 5 $\mathrm{ka} \mathrm{BP}$, with paleosol complexes developed in the Loess Plateau, and decreased SI values after $5 \mathrm{ka}$ $\mathrm{BP}$, with recent Holocene loess deposited. Similar geological evidence was discovered in the $\mathrm{QH}-$ $16 \mathrm{~A}$ core of Qinghai Lake. Figure 2 indicates $\delta^{18} \mathrm{O}$ values (in per mil) of ostracod shells in the QH$16 \mathrm{~A}$ core (Zhang 1989). Between 10.2 and $5 \mathrm{ka} \mathrm{BP}, \delta^{18} \mathrm{O}$ was negative with frequent fluctuations, reflecting a warm climate, whereas after $5 \mathrm{ka} \mathrm{BP}, \delta^{18} \mathrm{O}$ gained positive values, although several fluctuations occurred, and the climate generally changed to cool and dry conditions.

In recent years, Zheng (1989) discovered that, from 10-5 ka BP, Shala Wushu (north of the Loess Plateau) vegetation indicated no distinct boundary between early and middle Holocene, but after 5 ka BP, vegetation decreased rapidly. Zhang, Zhang and Yang (1989) also found that, from 13.8-7.5 ka BP, the climate was suitable for black loam soil development in Longdong, Shaanxi Province. Yang (1989) proposed that a low temperature event occurred in north China at ca. $5 \mathrm{ka} \mathrm{BP}-$ Quercus concentration decreased to a minimum at ca. 5030 BP east of the HeBei Plain. Scandinavia, Canada, Greenland and North America also provide evidence of a simultaneous low-temperature event.

It is worth noting that $c a .12 .5 \mathrm{ka} \mathrm{BP}$, a weakly pedogenic paleosol developed in the Baxie profile and a pedogenic carbonate nodule horizon developed in the Luochuan profile between 13 and $12 \mathrm{ka}$ $\mathrm{BP}$, demonstrating the recurrence of mild climate after the last glacial maximum. These changes cannot be seen within the southern Bei Zhuang Cun and Bai Ma Po profiles. The Baxie profile displays a loess layer $c a .1 .12 \mathrm{~m}$ thick that formed $c a .10 \mathrm{ka}$ BP. The Luochuan profile indicates that a 
30-cm-thick loess layer formed between the bottom of the Holocene paleosol (10.5 ka BP) and a carbonate horizon dating to $c a .12,970 \mathrm{BP}$. These loess deposits indicate that a rapid cold and dry climatic event occurred from 11-10 ka BP. This coincides with the reworked loess (deposited under fluvial conditions) at around the same age range. The Bai Ma Po profile does not indicate these changes.

Thick black loam paleosol complexes were deposited between 10 and $5 \mathrm{ka} \mathrm{BP}$, recording the Holocene optimum in Renjiahutong and Bai Ma Po. This corresponds with a complex of paleosol and loess deposits at Bei Zhuang Cun. This could indicate possible flood conditions interspersed with paleosol formation. At Baxie to the west, the paleosols are also mixed with loess deposits. Hence, the southeast of the Loess Plateau seems to have experienced warmer, wetter conditions more consistently, which can be expected, because summer monsoons are likely to have affected this area to a greater extent.

\section{CoNCLUSIONS}

From $5 \mathrm{ka}$ BP to the present, the Loess Plateau was dominated by the deposition of loess. We propose that a twofold stratigraphic division of the Holocene in China-the early Holocene optimum, $10-5 \mathrm{ka} \mathrm{BP}$, characterized by the development of paleosol complexes, and late Holocene neoglaciation after $5 \mathrm{ka} \mathrm{BP}$, characterized by recent loess deposition. As indicated above, local effects have influenced the profiles mentioned in this study, and this seems to be dependent on geographical position within the plateau and on the landscape.

\section{ACKNOWLEDGMENTS}

Xiao Jule, Zheng Hongbo and Ren Jian Zhang took part in the field work, Zhang Jingzhao provided the TL ages, and most of the ${ }^{14} \mathrm{C}$ determinations were carried out in the ${ }^{14} \mathrm{C}$ Laboratory at ANU by Weijian Zhou as part of a Visiting Fellowship from August 1987 to August 1988. This study was supported as the 8.5 key project of the Chinese Academy of Sciences.

\section{REFERENCES}

An, Z. S., Kukla, G. J., Porter, S. C. and Xiao, J. 1991 Magnetic susceptibility evidence of monsoon variation on the Loess Plateau of central China during the last 130,000 years. Quaternary Research 36: 29-36.

An, Z. S., Porter, S., Kukla, G., and Xia, J. L. 1990 Magnetic susceptibility evidence of paleomonsoon variation in the Loess Plateau in the last $130 \mathrm{ka}$. KeXue Tong Bao 7: 529-532.

An, Z. S., Porter, S. C., Zhou, W. J., Lu, Y. C., Donahue, D. J., Head, M. J., Wu, X. H., Ren J. Z. and Zheng, H. B. 1993 Episode of strengthened summer monsoon climate of Younger Dryas age on the Loess Plateau of central China. Quaternary Research 39: 45-54.

An, Z. S., Xiao, J., Zhang, J. Z., Xie, J., Zheng, H. P. and Zhao, H. 1990 Monsoon and climatic history during the last 130,000 years in the Loess Plateau, China. In Loess Quaternary Geology Global Change. Beijing, Science Press: 108-114.

Gupta, S. K. and Polach, H. A. 1985 Radiocarbon Practices at ANU. Canberra, Australian National University: $171 \mathrm{p}$.
Head, M. J. (ms.) 1979 Structure and Chemical Properties of Fresh and Degraded Wood: Their Effects on Radiocarbon Dating Measurements. M.Sc. thesis, Australian National University: 103 p.

Head, M. J., Zhou, W. J. and Zhou, M. F. 1989 Evaluation of ${ }^{14} \mathrm{C}$ ages of organic fractions of paleosols from loess-paleosol sequences near Xian, China. In Long, A. and Kra, R. S., eds., Proceedings of the 13th International ${ }^{14} \mathrm{C}$ Conference. Radiocarbon 31(3): 680 696.

Heller, F. and Liu, T. S. 1984 Magnetism of Chinese loess deposits. Geophysical Journal of the Royal Astronomical Society 77: 125-141.

Kukla, G. and An, Z. S. 1989 Loess stratigraphy in central China. Palaeogeography, Palaeoclimatology, Palaeoecology 72: 203-225.

Liu, T. S., ed. 1985 Loess and the Environment. Beijing, China Ocean Press: 251 p.

McIver, R. D. 1962 Ultrasonics - A rapid method for removing soluble organic matter from sediments. Geochimica et Cosmochimica Acta 26: 343-345. 
Qiao, Y. L., Huang B. L., Shen C. D. and Zhou, M. F $1985{ }^{14} \mathrm{C}$ dating of loess. In Liu, T., ed., Loess and the Environment. Beijing, China Ocean Press: 48-53.

Stuiver, M. and Polach, H. A. 1977 Discussion: Reporting of ${ }^{14} \mathrm{C}$ data. Radiocarbon 19(3): 355-363.

Yang, Z. G. 1989 Discussion of low temperature event in 5 ka BP. Quaternary Research of China 8: 151-189.

Zhang, P. X., Zhang, B. Z. and Yang, W. B. 1989 On the model of post-glacial paleoclimatic fluctuation in Qinghai Lake region. Quaternary Sciences. 1: 66-77 (in Chinese).

Zhang, W. X. and Hu, S. X. 1989 The time and process of black-loam soil formation in Long Dong Loess Yuan. Kexue Tong Bao 16: 1252-1255.

Zheng, H. H. 1984 Holocene loess in the middle reach of the Huang He. Geochemistry 3: 234-246 (in Chinese). 1989 Some geological evidence of environmental change in the last 10,000 years in north China. Quaternary Sciences 1: 78-83 (in Chinese).

Zhou, W. J. and An, Z. S. $1991{ }^{14} \mathrm{C}$ chronology of Loess Plateau in China. In Liu T., ed., Quaternary Geology and Environment in China. Beijing, Science Press: 192-200.

Zhou, W. J., An, Z. S., Lin, B. H., Xiao, J., Zhang, J. Z., Xie, J., Zhou, M. F., Porter, S. C., Head, M. J. and Donahue, D. J. 1992 Chronology of the Baxie loess profile and the history of monsoon climates in China between 17,000 and 6000 years BP. In Long, A. and Kra, R. S., eds., Proceedings of the 14th International ${ }^{14} \mathrm{C}$ Conference. Radiocarbon 34(3): 818-825.

Zhou, W. J., Zhou, M. F. and Head, J. $1990{ }^{14} \mathrm{C}$ chronology of Bei Zhuang Cun sedimentation sequence since 30,000 years BP. Chinese Science Bulletin 35(7): 567-572. 